\title{
The Impact of Information Technology Application on Enterprise Marketing Performance Based on the Mediation Effect of Marketing Ability
}

\author{
Achmini Diati \\ Department of Business Administration of State Polytechnic of Malang Indonesia \\ achmad.zaini@polinema.ac.id
}

\begin{abstract}
The goal of this study is to examine the role of information technology as a moderating variable for entrepreneurial and marketing orientation in SMEs that export through intermediaries. From May to June 2019, this study was conducted on registered exporting SMEs in the East Java Cooperatives Department in Greater Malang, East Java, Indonesia. This study used 50 exporting small and medium - sized businesses as samples. The analysis method used in this study is Partial Least Squares (PLS). The study's findings revealed that market orientation variables have a positive impact on both entrepreneurial orientation and marketing performance. The entrepreneurial orientation variable has no discernible effect on marketing performance. Market orientation does not affect information technology. Entrepreneurial orientation has a significant impact on information technology. Marketing performance is unaffected by information technology. Market orientation has no discernible impact on marketing performance via information technology. Through information technology, the variable of entrepreneurial orientation has no significant effect on marketing performance. These findings indicate that because SMEs rely on intermediaries to export their products, the variables of entrepreneurial orientation, market orientation, and information technology cannot be developed optimally to support marketing performance.
\end{abstract}

Keywords: marketing orientation, entrepreneurial orientation, information technology, marketing performance, SMEs, Greater Malang

\section{Introduction}

Small and medium - sized enterprises (SMEs) must be prepared from the start for a very rapid market development and changes of customer demand. Market - oriented small and medium - sized businesses are constantly responding to customer needs [5]. Creativity and innovation must continue to grow, so SMEs must be creative and innovative in order to succeed [44]. Entrepreneurs of SMEs must be able to identify and actively pursue efforts to acquire and retain customers who benefit from innovative approaches to risk management, resource efficiency, and value creation. [30]. The ability of SMEs entrepreneurs to serve customers well by developing their entrepreneurial spirit and mastery of information technology will improve their marketing performance.

\section{Literature Survey}

\subsection{Market Orientation}

Market orientation is a set of processes and activities that aim to create and satisfy customers by continuously assessing their wants and needs. [42]. Furthermore, market orientation is an organizational culture that fosters an efficient method of serving buyers in order to provide superior value to both businesses and consumers. [31]. It is critical to generate and disseminate market orientation in order to increase the number of consumers. Market orientation has an effect on the company's durability in comparison to competitors, and increasing customer satisfaction can also lead to a sustainable competitive advantage in tough competition.

Finally, market orientation is capable of effectively gaining and maintaining a competitive advantage by planning and coordinating all organizational parts or functions in order to satisfy the customer. Market orientation emphasizes identifying and monitoring customer needs and responding to them through the creation and development of products or services. The best business culture will be one that is committed to retaining creative value for customers. Market orientation consists of three components: customer orientation, competitor orientation, and inter - functional coordination [31]. Customer and competitor orientations must be carried out in order to obtain information on buyers and competitors, and functional coordination must be used to support all related functional components. Previous research [24], [36] discovered that market orientation has an effect on company performance. Market - oriented and entrepreneurial activities improve company performance even more if they make optimal use of information technology. [22]

H1. The marketing orientation's effect on entrepreneurial orientation

H2: The market orientation's effect on marketing performance

H3. The market orientation's effect on information technology

\subsection{Information Technology}

A set of technologies used by an organization to process and disseminate information in a variety of ways is referred to as information technology. Because the data and message exchange process occurs without time and space constraints, 
information technology assists the company's operationalization effectively and efficiently. Information technology is defined as a company's ability to mobilize and disseminate information technology - based resources in addition to other resources and capabilities [49]. Information technology capability is an inherent part of the company's process and routine activity that enables the company to generate asset value [38]. Because information technology can be used to make work more efficient, mastery of it can reduce business costs. Information technology can be defined as a device that mediates communication between communicators and communicants in order for information to be properly conveyed. The best tool for identifying problems in a company is information technology. Companies benefit from information technology in the following ways: internal development to solve business resource problems; external development to expand markets: support for companies, purchase orders, dealing directly with buyers and more business people, making it easier to sell even to buyers from abroad. According to the findings of [8], [32], information technology has an impact on marketing performance. Companies must focus on the organization's goals and mission by leveraging information technology to ensure that investment planning is carried out in accordance with company conditions at a low cost while providing maximum value [16]. The use of information technology fosters the implementation of creative work [29]. H6: The information technology's influence on marketing performance

\subsection{Entrepreneurship Orientation}

Entrepreneurship is defined as the use of one's creative and innovative abilities as the foundation and means of achieving success [44]. According to [20], entrepreneurial marketing is an integrated concept in a changing era. Entrepreneurship marketing is the proactive identification of efforts to reach and retain customers who deliver profits through the use of innovative approaches to risk management, resource efficiency, and resource value [30]. The application of entrepreneurial behavior can be seen in an innovative, proactive, and courageous risk - taking approach to business execution. Because of three dimensions [27], [44], an organization will conduct a business - management process: innovative capacity, risk - taking capability, and a proactive attitude. A number of indicators can be used to measure a businessman's entrepreneurial capacity based on the various indicators related to entrepreneurship capacity. These indicators included autonomy, proactivity, and risk taking. They are used as indicators of the entrepreneurial orientation variable in this study. Previous research [19], [46], and [7] discovered that entrepreneurial orientation influences marketing performance.

H3: The entrepreneurial orientation's effect on marketing performance

H4. The entrepreneurial orientation's effect on information technology

\subsection{Marketing Performance}

The marketing performance of an enterprise is the success of new products and market development, which can be measured by sales growth and market share [34]. Marketing performance is derived from a company's overall marketing process, which can be viewed as a concept that quantifies the extent of product market achievement. Customer growth, sales growth, and market share are three primary indicators of good marketing performance, which ultimately leads to increased company profitability [11]. According to [43], the increase in sales is determined by the volume of sales and the number of customers who consume at a consistent level. This increase in sales shows how many product units were successfully sold to consumers, as well as how much money was made as a result of those sales. The higher the sales value, the more products are sold to consumers successfully. Customer growth is the rate at which a company's customers grow. Profitability growth refers to the increase in the company's profits. Meanwhile, market share depicts how much control the handled product contributions have over the same type of product market as competitors. Marketing performance is a factor that is frequently used to quantify the impact of a strategy. This study employs a market - based quantification of marketing performance that employs four indicators: sales growth, market growth, market share growth, and profitability growth. It was discovered that there is a significant relationship between market orientation and marketing performance that is mediated by information technology [47], which is supported by the important role of information technology in marketing activities [14]. Also, according to [33], small and medium - sized businesses that do not use information technology will lose their competitive advantage, making it impossible for them to operate at high levels of efficiency and effectiveness. In terms of the importance of information technology in entrepreneurship, [37] asserts that information technology plays a critical role in effectively directing the work of all company members.

H7. The market orientation's influence on marketing performance through information technology

H8. The entrepreneurial orientation's effect on marketing performance through information technology

\section{Methods / Approach}

This is an explanatory study in which the data is gathered through a survey method based on the responses of the respondents to a questionnaire. Market orientation, entrepreneurial orientation, information technology, and marketing performance are all variables to consider.

\subsection{Population and Sample}

This study's population consists of all owners of exporting SMEs in Greater Malang (Malang City, Batu City, and Malang Regency) who are registered with the Cooperatives Department in East Java. Up to 50 companies were sampled, but only 43 are eligible for processing at the data analysis stage.

\subsection{Research Concept Framework}




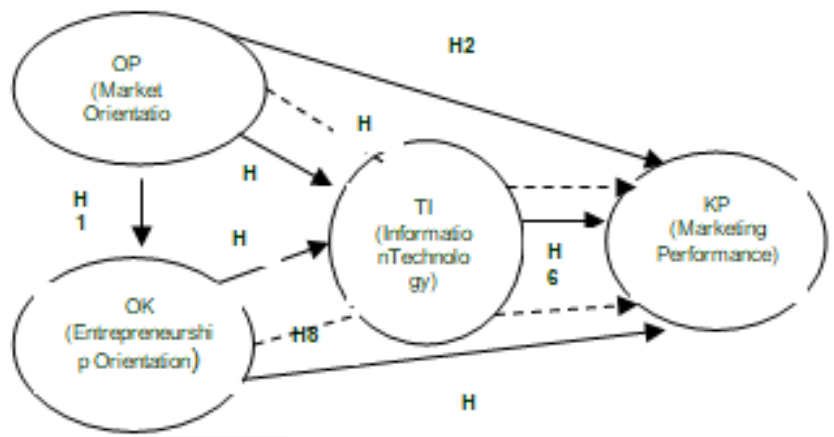

Figure 1: Research Concept Framework

\section{Data Analysis}

This study employs a Partial Least Squares (PLS) analysis tool that includes three relationship sets: (1) an inner model, (2) an outer model, and (3) a weight relationship. PLS employs algorithm iteration, which consists of an ordinary least square series of analysis. [12]

\section{Results / Discussion}

\subsection{Respondents' Characteristics by Type of SME Products}

Table 1 shows that the top three types of products produced by exporting SMEs in the Greater Malang region are handicrafts, souvenirs, garments, and fruit chips, accounting for $70 \%$ of total production. Souvenir items contribute significantly to the tourism industry, which is being promoted by the government. SMEs contributing through souvenir products (creative industries) to increase GDP from 6.3 percent to 8 percent [1]

Table 1: Frequency distribution based on type of SMEs product

\begin{tabular}{|c|c|c|c|}
\hline No & Types of SME Products & $\begin{array}{c}\text { Frequency } \\
\text { (Unit) }\end{array}$ & Percentage \\
\hline 1 & Souvenirs handicrafts & 15 & $35 \%$ \\
\hline 2 & Furniture & 2 & $5 \%$ \\
\hline 3 & Garments & 9 & $21 \%$ \\
\hline 4 & Music Instruments & 3 & $7 \%$ \\
\hline 5 & Fruit Chips & 6 & $14 \%$ \\
\hline 6 & Cultivation & 3 & $7 \%$ \\
\hline 7 & Replica costume & 1 & $2 \%$ \\
\hline 8 & Light machine & 2 & $5 \%$ \\
\hline 9 & Food and Honey Products & 2 & $5 \%$ \\
\hline & Total & 43 & $100 \%$ \\
\hline
\end{tabular}

Source: Primary data processed (2019)

\subsection{Respondents' Characteristics by Export Destination Country}

Table 2 shows data on the top export destinations for SMEs in the Greater Malang region, which includes five continents: Asia, Australia, Europe, America, and Africa. Malaysia, Singapore, Japan, Saudi Arabia, Thailand, Brunei, Hong Kong, China, Korea, the Philippines, and New Guinea are among the Asian export destinations. With 67 percent of total export destination countries, Asian countries are the most important export destinations, Malaysia and Singapore, in particular, have similar tastes to Indonesian consumers. Meanwhile, export destination countries in Europe are ranked second (16\%), in the following order: Germany, France, Italy, England, and Spain are all represented.

Table 2: Frequency Distribution Based on Export Destination Countries

\begin{tabular}{|c|c|c|c|}
\hline \multicolumn{2}{|c|}{ Characteristics of Respondents } & Frequency (SME) & Percentage \\
\hline \multirow{3}{*}{$\begin{array}{c}\text { Export } \\
\text { Destination } \\
\text { continent }\end{array}$} & Asia & 82 & $67 \%$ \\
\cline { 2 - 4 } & Australia & 11 & $9 \%$ \\
\cline { 2 - 4 } & Europe & 19 & $16 \%$ \\
\cline { 2 - 4 } & America & 8 & $7 \%$ \\
\cline { 2 - 4 } & Africa & 2 & $2 \%$ \\
\cline { 2 - 4 } & Total & 122 & $100 \%$ \\
\hline
\end{tabular}

Note: One SME may has export destination country more than one

Source: Primary data processed (2019)

\subsection{Respondents' Characteristics Based On Export Method}

Table 3 shows the export methods used by Malang's SMEs, which are mostly (69.77\%) done through intermediaries. These findings indicate that SME export administration capability is limited, as are their capital capacities. Because of the high cost of purchasing or renting containers, as well as the high cost of transportation, SME entrepreneurs prefer to export through intermediaries. Exporting through intermediaries eliminates the need for them to deal with export administration, which most of them do not understand. This method of exporting has an impact on SME entrepreneurs' reliance on intermediaries. However, there are those who are already exporting on their own. Entrepreneurs who take the risk of exporting on their own usually have a solid understanding of export administration or procedures, as well as export - import training from a reputable institution.

Table 3: Frequency Distribution Based on Export Method

\begin{tabular}{|c|c|c|c|}
\hline \multicolumn{2}{|c|}{ Characteristics of Respondents } & $\begin{array}{c}\text { Frequency } \\
\text { (person) }\end{array}$ & $\begin{array}{c}\text { Percentage } \\
(\%)\end{array}$ \\
\hline \multirow{2}{*}{$\begin{array}{c}\text { Export } \\
\text { Method }\end{array}$} & Export By self & 13 & 30,23 \\
\cline { 2 - 4 } & Through an intermediary & 30 & 69,77 \\
\cline { 2 - 4 } & Total & 43 & 100 \\
\hline
\end{tabular}

Source: Primary data processed (2019)

\section{Assessing the Outer Model (Measurement Model)}

The indicator is said to be valid if the convergent validity has a loading value of at least 0.6 [12]. while the reliability test using the Composite Reliability value yields a value greater than 0.70 [12]. The calculation results show that all indicators are valid and reliable (Figure 2)

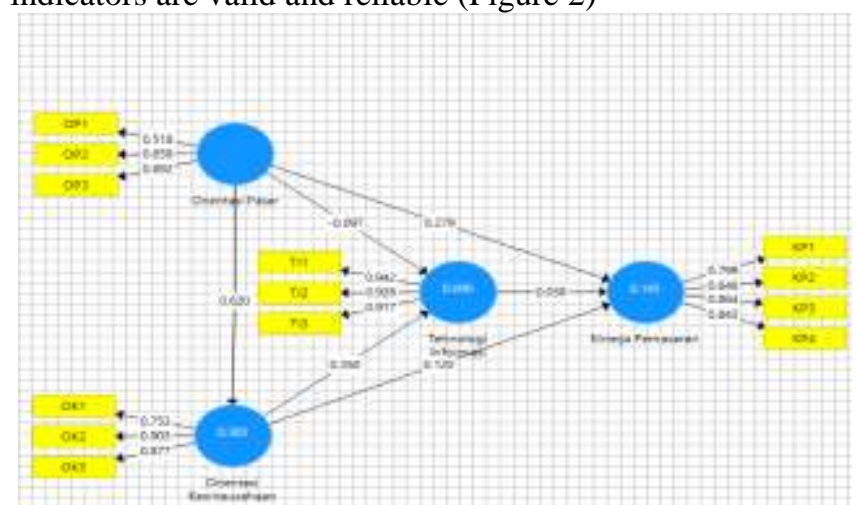

Figure 2: Structural Model of Research Results 
Source: Primary data processed (2019)

\section{Assessing The Inner Model (Structural Model)}

The inner Model can be viewed from the R - square value to ensure that the Goodness of Fit Model can be measured. The Goodness of Fit Model has a value of Q2 = 1 - 1 - 0.385 (1 $0.90)(1-0.145)=0.5215$. This value demonstrates that the relationship between marketing orientation (OP), entrepreneurial orientation (OK), information technology (IT), and marketing performance (KP) variables is 52.15 percent, with the remaining 47.85 percent explained by variables other than model and error.

\section{Hypothesis Testing}

The SmartPLS bootstrap resampling method is used for hypothesis testing. The test was carried out by comparing the $\mathrm{t}$ - count value to the $\mathrm{t}-$ table value of $1.683(=0.05$ and $\mathrm{df}=\mathrm{n}-\mathrm{k}, \mathrm{df}=43-4=39$ ). The $\mathrm{t}$ value that is greater than the $\mathrm{t}$ - table value of 1,683 is considered significant, and thus the hypothesis is accepted. Table 4 demonstrates that the path coefficient value and the $\mathrm{t}$ - statistic column of the $\mathrm{HI}, \mathrm{H} 2$, and H5 correlation have a significant effect, indicating that the hypothesis is accepted. Meanwhile, H3, $\mathrm{H} 4$, and $\mathrm{H} 6$ are ineffective, and the hypothesis is rejected.

Table 4: Direct Influence Hypothesis Testing

\begin{tabular}{|c|c|c|c|c|c|}
\hline Hypothesis & Correlation & $\begin{array}{c}\text { Path } \\
\text { Coefficient }\end{array}$ & $\mathrm{t}-$ Stat. & \multicolumn{2}{|c|}{ Remarks } \\
\hline H1 & OP $\rightarrow$ OK & 0.620 & 6.081 & Sig & accepted \\
\hline H2 & OP $\rightarrow$ KP & 0.279 & 1.712 & Sig & accepted \\
\hline H3 & OK $\rightarrow$ KP & 0.120 & 1.508 & Not Sig & rejected \\
\hline H4 & OP $\rightarrow$ TI & -0.097 & 0.222 & Not Sig & rejected \\
\hline H5 & OK $\rightarrow$ TI & 0.350 & 1.864 & Sig & accepted \\
\hline H6 & TI $\rightarrow$ KP & 0.058 & 0.789 & Not Sig & rejected \\
\hline
\end{tabular}

Remarks: $\mathrm{t}$ - Stat $=$ significant at $\alpha=0.05$

Source: Primary data processed (2019)

Table 5: Path Coefficient of Indirect Effect

\begin{tabular}{|c|c|c|c|c|c|c|}
\hline \multirow{2}{*}{ Hypothesis } & \multicolumn{2}{|c|}{ Variable } & \multirow{2}{*}{$\begin{array}{c}\text { Path } \\
\text { Coeff. }\end{array}$} & Remarks & $\begin{array}{c}\text { Mediation } \\
\text { Type }\end{array}$ \\
\cline { 2 - 5 } & Exogen & Mediation & Endogen & Marketing Performance \\
H7 & Market Orientation (OP) & Information Technology (TI) & $\begin{array}{c}\text { O, 006 } \\
\text { Not Sig }\end{array}$ & Non Mediation \\
\hline H8 & Entrepreneurial Orientation (OK) & Information Technology (TI) & $\begin{array}{c}\text { Marketing Performance } \\
\text { (KP) }\end{array}$ & 0.02 & Not Sig & Non Mediation \\
\hline
\end{tabular}

Source: Primary data processed (2019)

\section{Discussion of Research Results}

\section{1) The marketing orientation's effect on entrepreneurial orientation}

Hypothesis 1 (H1) testing demonstrates that marketing orientation has a significant impact on the entrepreneurial orientation of export SMEs, as evidenced by a coefficient value of 0.620 and a $t$ - statistic value of 6.081 . The $t$ statistic value is greater than the $\mathrm{t}$ - table value, which is 1.683 (significant at $=0.05$ ).

These findings suggest that SMEs owners' commitment to understanding consumers, competitors, and coordination between functional sections of their companies has a significant impact on their entrepreneurial activities, allowing them to operate independently, be proactive, and have the courage to take risks. SMEs conduct marketing activities by focusing on the wants and needs of their customers. SMEs carry out activities such as monitoring employees' seriousness in serving customer needs, establishing strategies based on the desire to provide added value to customers, understanding customer needs, and providing high customer satisfaction. SMEs also consider their competitors' strategies by regularly monitoring their marketing programs and responding quickly to their actions. Furthermore, SMEs coordinate between departments within the company to ensure that all policies issued always satisfy customers.

\section{2) The market orientation's effect on marketing} performance

Hypothesis $2(\mathrm{H} 2)$ testing reveals that marketing orientation has a significant positive impact on marketing performance, as evidenced by a coefficient value of 0.279 and a $t$ - statistic value of 1.712 . The $t$ - statistic value exceeds the $t-$ table value of 1.683. This finding is consistent with Narver and Slater's (1990) belief that interfunctional coordination can increase value for target customers. Furthermore, interfunctional coordination serves several other purposes, including facilitating communication between different organizational functions, improving information exchange between associated organizational functions, and informing current market trends. As a result, it can improve the independence of the functional parts and, ultimately, encourage the company to provide products that customers truly require.

The findings of this study are consistent with the findings of research conducted by [6]; [24]; [2]; [35]; [36], which discovered that market orientation variables had a significant impact on the company's marketing performance.

The findings of a study on the export of SMEs to Greater Malang remind owners to continue paying attention to the market in order to meet the changing needs and desires of the customer. Owners will see an increase in sales value, number of customers, market share, and profitability if they pay more attention to the customer.

\section{3) The entrepreneurial orientation's effect on marketing performance}

The hypothesis 3 testing $(\mathrm{H} 3)$ reveals that entrepreneurial orientation has no significant impact on marketing performance. This result is distinguished by a coefficient value of 0.120 and a $t$ - count value of 1.508 , both of which are less than the $\mathrm{t}$ - table value of 1.683. These findings indicate that entrepreneurial orientation, as measured by indicators such as autonomy, risk - taking, and proactiveness, has no significant impact on marketing performance. Entrepreneurs with a strong entrepreneurial 
orientation should be able to achieve good results in theory. Entrepreneurs who are brave enough to take risks and view uncertainty as a challenge, as well as those who are willing to enter unfamiliar markets and accept failures, will be successful [25]. This statement, however, does not apply to SMEs in Greater Malang. This result is closely related to how SMEs in Greater Malang export their products, with the majority $(69.77 \%)$ using intermediaries. Intermediaries have handled all actions relating to decision - making autonomy, risk - taking, and proactiveness. The findings of this study contradict those of [19], [46], [2], [23], [7], [13], and [25], which found a significant positive impact of entrepreneurial orientation on the company's marketing performance.

\section{4) The market orientation's effect on information technology}

The hypothesis 4 Testing (H4) demonstrates that market orientation has no significant positive impact on information technology. This result is distinguished by a coefficient value of - 0, 097 and a $\mathrm{t}$ - count value of 0,222 , both of which are less than the $t$ - table value of 1,683 . These findings indicate that market orientation activities carried out by SMEs, such as paying attention to customers and competitors, as well as coordinating inter - functional activities, have no significant positive impact on information technology.

The findings of this study contradict the findings of [4], which indicate that customer - oriented SMEs require information technology to provide better service to customers. The findings of this study also contradict an opinion expressed by [40], who claims that a market oriented company requires information technology to communicate with customers via various mass media.

The ability to develop information technology and capitalize on its application is a critical factor in today's tough business competition. However, in the case of SMEs in Greater Malang, all activities related to customer service, competition monitoring, and inter - functional activity coordination are carried out by intermediaries, so SMEs have only followed the advice of intermediaries.

\section{5) The entrepreneurial orientation's effect on information technology}

The results of hypothesis 5 Testing (H5) indicate that entrepreneurial orientation has a significant impact on information technology for SMEs. This testing yields a coefficient value of 0.350 and a t - count value of 1.864 , both of which are greater than the $\mathrm{t}$ - table value of 1.683 . These findings demonstrate that whatever SMEs do in their entrepreneurial activities can have an impact on their information technology. Technology's role in improving SMEs' business services is to support their performance. In which information technology and business are closely intertwined [17], information technology and business are becoming increasingly intertwined. These findings suggest that SMEs in Greater Malang can use information technology to boost their entrepreneurship.

The findings of this study are consistent with research from [9], which shows that companies require information technology to implement entrepreneurial orientation.
Furthermore, the findings of this study are consistent with the findings of the research conducted by [41], which show that the use of good information technology causes entrepreneurial orientation to evolve rapidly. The findings of this study agree with [1], who states that entrepreneurs must master technology as the primary support in entrepreneurship. Similarly, [48] believes that the world of business and organizations in general rely on information technology to carry out daily activities and achieve future goals.

\section{6) The information technology's influence on marketing performance}

The results of hypothesis 6 testing (H6) show that information technology has no significant impact on the marketing performance of SMEs. This result is distinguished by a coefficient value of 0.058 and a $\mathrm{t}$ - count value of 0.789 , both of which are less than the $\mathrm{t}-$ table value of 1.683 . These findings indicate that information technology, as measured by indicators such as promotional media, order - making media, and communication media, has no discernible impact on marketing performance.

This insignificant result can be attributed to the way SMEs in Greater Malang export their products (69.77 percent), which rely on intermediaries. Whatever SMEs do with information technology, as long as marketing is still dependent on intermediaries, the use of technology will be ineffective. All promotions and communications with overseas buyers are handled by intermediaries, whereas SMEs only carry out agreements made by intermediaries. This study's findings contradict research from [3]; [4]; [10]; [28]; [8]; [32], which discovered a significant relationship between information technology variables and a company's marketing performance.

\section{7) The market orientation's effect on marketing} performance through information technology

Hypothesis testing 7 (H7) demonstrates that market orientation has no significant effect on marketing performance via information technology, as evidenced by a coefficient of - 0.006. These findings demonstrate that, while SMEs have engaged in market orientation activities involving customers, competitors, and interfunctional coordination, these activities are unable to leverage information technology to improve marketing performance. This result contradicts [12], who believes that inter functional coordination can lead to increased value for target customers. Inter - functional coordination should be capable of facilitating communication between different organizational functions and improving information exchange between associated organizational functions. Furthermore, interfunctional coordination should be capable of informing the most recent market trends. Furthermore, it can increase the independence of the functional parts, encouraging the company to provide products that are truly needed by customers. However, this does not apply to SMEs in Greater Malang because SMEs rely heavily on intermediaries to export their products (69.77 percent). As a result, whatever SMEs do in information technology to support market orientation and improve marketing performance is difficult to put into practice. 
8) The entrepreneurial orientation's effect on marketing performance through information technology

The results of hypothesis 8 (H8) show that entrepreneurial orientation has no significant effect on marketing performance via information technology. The coefficient value of 0.020 characterizes this output. These findings demonstrate that information technology, as measured by indicators such as promotional media, order media, and communication media, cannot significantly influence marketing performance by mediating entrepreneurial orientation. The activities of SMEs using various information technology media to promote their products, such as social media, websites, blogs, and others, cannot help entrepreneurship orientation to influence SMEs marketing performance. Similarly, using various internet based media to obtain purchase orders cannot assist entrepreneurship in influencing the marketing performance of SMEs. Furthermore, the use of information technology as a means of communication between SMEs and their customers cannot influence the performance of SMEs marketing.

These findings demonstrate that, no matter what SMEs do in their entrepreneurial activities, they cannot use information technology to influence their marketing performance. Entrepreneurs with a strong entrepreneurial orientation should be able to achieve good results in theory. Entrepreneurs who are brave enough to take risks and view uncertainty as a challenge, as well as those who are willing to enter unfamiliar markets and accept failure, will be successful [25]. This statement, however, does not apply to SMEs in Greater Malang, where entrepreneurial orientation has no effect on marketing performance via information technology. The findings are inextricably linked to the situation of SMEs in the Greater Malang region, which are heavily reliant on intermediaries $(69.77 \%)$ when exporting their products.

\section{Conclusion}

According to the findings of this study, there are three relationships between variables that have an effect on each other: the market orientation variable has a positive effect on both entrepreneurial orientation and marketing performance. Furthermore, the entrepreneurial orientation variable has a significant impact on information technology.

The study also shows that there are five relationships that do not affect each other, namely: entrepreneurial orientation variables do not have a notable effect on marketing performance, market orientation variables do not have a notable effect on information technology, information technology variables do not have a notable effect on marketing performance, market orientation variables do not have a notable effect on marketing performance, market orientation variables do not have a notable effect on marketing performance, market orientation variables do not have a notable effect on marketing performance, market orientation variables do not have a notable effect

The conclusion from all of those results is that where small and medium - sized enterprises rely on intermediaries to export their products, the variables of entrepreneurial orientation, market orientation and information technology cannot be optimally developed to support marketing performance.

\section{Future Scope}

The research benefits are as follows: first, the findings can be used as a reference for exporting SMEs in Greater Malang in terms of information technology use, entrepreneurial orientation, and marketing orientation; second, the findings can be used as a guide for regional governments to develop policies to assist exporting SMEs in improving their marketing performance.

\section{References}

[1] Abu Bakar, Ahmad Zakir, 2011, Wirausahawan Harus MelekTehnologiInformasi, Kompas. com, diaksestgl 10 Oktober 2018

[2] Affendy, AH; Asmat, Nizam Abdul Talib, 2015, Entrepreneurial Orientation Effect on Market Orientation and SME's Business Performance - A SEM Approach, Review of Integrative Business and Economics Research Vol 4 No 3 pp 259 - 271

[3] Alghamdi, Sultan and Bach, Christian, 2014, Technological Factors to Improve Performance of Marketing Strategy, ASEE Zone I Conference, University of Bridgeport CT USA

[4] Alsamydai, MahmoodJasim and Dajani, DimaMousa, 2016, Measuring the impact of information technology use on the marketing performance of business organizations, International review of Management and Business ResearchVol 5 Issue 3 pp.1068 - 1082

[5] Baker, W. E. and Sinkula, J, M. (2002), "Market orientation, learning orientation and product innovation: developing into the organization's black box", Journal of Market - focused Management, Vol.5 No.1, pp.5 - 23.

[6] Bharadwaj, S. G, P. R. Varadarajan, and Fahy, J., 1993, Sustainable Competitive Advantage in Service Industries: A Conceptual Model and Research Propositions, Journal of Marketing, Vol.57, Oktober pp.83 - 99,

[7] Bhuian, S. N., Habib, M., 2004, Relationship Between Entrepreneurship, Market Orientation and Performance A Test in Saudi Arabia, Journal of Transnational Management, Vol 10 issue pp.79 - 98

[8] Borges, M., Hoppen, N., Luce, F. B., 2009, Information technology impact on market orientation in e - business, Journal of Business Research, Volume 62, Issue 9, September 2009, pp.883 - 890

[9] Castellanos, Rosa Maria Munos; Pablo, Jesus David Sanches; Pardo, Isidro Pena Gracia; Salinero, Yolanda, 2016, The Effects of Technology Entrepreneurship on Customers and Society: A Case Study of A Spanish Pharmaceutical Distribution Company, Frontier in Psychology Vol 7 Article 978

[10] Clarismary, O. C., 2015. "Change in Information Technology and OrganizationalPerfomance : a study of Consolidated Hallmark", International Journal of 
Management and Commerce Innovations, Vol.3, No.1, pp.579-587.

[11] Ferdinand, A., 2003. Sustainable Competitive Advantage: SebuahEksplorasi Model konseptual. FakultasEkonomiUniversitasDiponegoro. Semarang

[12] Ghozali, I.2006. Structural Equation Modeling Metode Alternatifdengan Partial Least Square. BadanPenerbit Universitas Diponegoro, Semarang.

[13] Hazmi, A. F, Analisispengaruhsikapkewirausahaan, orientasipasardanpembelajaranorganisasiterhadapkin erja, http: //www.eprints undip. ac. id

[14] Hernandez, M. G. and Coronas, T. T. , 2009, Information Communication Technologies and City Marketing: Digital Opportunities for Cities Around the World, Edition: 1, Information Science Reference, ISBN 10: 1605661341 ISBN 13: 9781605661353

[15] Ibraheem, Sulieman, 2013, The Impact of Marketing Orientation Strategy on Performance of Commercial Banks in Jordan, International Journal of Business Information System Volume 14 Issue 3, September 2013 pp 261 - 279

[16] Jean, R., Sinkovics, R. R. and Kim, D. (2008), "Information technology and organisational performance within international business to business relationships: a review and an integrated conceptual framework", International Marketing Review, Vol.25 No.5, pp.563 - 583

[17] Johnston, Chris, 2010, Bill Gates: 101 Greatest Business Lessons, Inspiration and Quotes, Amazon. com USA

[18] Julian, Craig C., 2010, The Market Orientation Marketing Performance Relationship - The Empirical Link in International Joint Ventures, International Journal of Global Market Vol.3 No.4 pp 414 - 431

[19] Kiyabo, K., and Isaga, N., 2020, Entrepreneurial orientation, competitive advantage, and SMEs' performance: application of firm growth and personal wealth measures, Journal of Innovation and Entrepreneurship vol.9, Issu 12, pp.1 - 15,

[20] Kotler, P, 2001, Marketing Management, Prentice Hall, Upper Saddle

[21] Lapian, Adelina Agnes; Massie, James; Ogi, Imelda, 2016,

PengaruhOrientasiPasardanInovasiProdukTerhadapKin erjaPemasaranPada PT BPR Prisma Dana Amurang, Jurnal EMBA Volume 4 Nomer 1 Maret 2016 hal.1330 $-1339$.

[22] Larina, Y. S. and Romanenko, O. O., 2015, A new role of marketing and communication technologies in business and society: local and global aspects, Publisher: KHUSAR Gr o u p and Publishing House Science and Innovation Center, Ltd. St. Louis, Missouri, USA., ISBN 978 - 0 - 615 - 67156 - 7.

[23] Li, Y. H.; Huang, J. W.; Tsai, M. T.; 2009, Entrepreneurial orientation and firm performance: The role of knowledge creation process. Journal of Industrial Marketing Management, Vol 38, pp.440449

[24] Li, Y., Zhao, Y. Tan, J., Liu, Y. , 2008, Moderating
Effects of Entrepreneurial Orientation on Market Orientation-Performance Linkage: Evidence from Chinese Small Firms, Journal of Small Business Management, Volume46, Issue1 PP.113 - 133

[25] Looy, V. B., Debackere, K. \&Andries, P., 2003. Policies to stimulate regional innovation capabilities via university - industry collaboration: an analysis and an assessment. R\&D Management, 33 (2), pp.209 229.

[26] Manek, Daniel, 2013, Analisis Pengaruh Orientasi Pasar TerhadapKinerjaPemasaranPada Perusahaan Pengolahan di Kota Semarang, JurnalSainsPemasaran Indonesia Volume XII No.2 September 2013 pp.121 148.

[27] Matsuno, K., Mentzer, J. T. and Ozsomer, A.2002, The effects of entrepreneurial proclivity and market orientation on business performance, Journal of Marketing, Vol.66, pp.18 - 32.

[28] Mazidi, Achmad Reza Karimi; Amini, Alireza and Latifi, Meisam, 2014, The impact of information technology capability on firm performance; a focus on employee - customer profit chain, Iranian Journal of Management Studies (IJMS) Vol.7 N0.1 pp.95 - 120

[29] Mitchell, W. J., Inouye, A. S. , Blumenthal, M. S. , 2003, Beyond Productivity: Information, Technology, Innovation, and Creativity, Illustrated edition, Publisher: National Academies Press ISBN 10: 0309088682

[30] Morris, H., Lewis, P. S, 2002. The Determinants of Entrepreneurial Activity, Implication for Marketing. European Journal of Marketing. Vol.29, No.7.

[31] Narver, J. C., \&Slater, S. F.1995. The Effect of Market Orientation on Business Profitability", Journal of Marketing. pp. $20-35$.

[32] Noh, J. and Fitzsimmons, J. A. (1999), "Effect of information technology on marketing performance of Korean service firms", International Journal of Service Industry Management, Vol.10 No.3, pp.307 - 321

[33] Passerini, K., Tarabishy, A. E., Patten, K., 2012, Information Technology for Small Business: Managing the Digital Enterprise, Edition: 1, Publisher: Springer Verlag New York, ISBN 13: 978 - 1 - 4614 - 3040 - 7

[34] Pelham, A. M., \& Wilson, David T. (1996). A longitudinal study of the impact of market structure, firm structure, strategy, and market orientation culture on dimensions of small - firm performance. Journal of the Academy of Marketing Science, 24 (1), pp.27-43.

[35] Pertiwi, YunitaDwidanSiswoyo, BambangBanu, 2016, PengaruhOrientasiPasarTerhadapKinerjaPemasaranpad a UMKM KripikBuah di Kota Batu, Syariah Paper Accounting FEB UMS, ISSN 2460 - 0784

[36] Purnamasari, S., Wijaya, A., 2020, PengaruhOrientasiPasar, OrientasiKewirausahaan Dan KemampuanPemasaran, TerhadapKinerjaBisnisUmkm Clothing Line, Business Management Journal Vol.16 (No.1): pp.53 - 64. Variabel orient asipemasaranberdampakpadakinerjapemasaran

[37] Reynolds, G. W., 2009, Information technology for managers Edition: 1, Publisher: Course Technology / Cengage Learning ISBN 13: 9780324792935, ISBN: 
032479293X

[38] Richardson, V. J., Subramani, M., \&ZmudR. W., 2003, Benefiting from Information Technology Investments: the Role of IT Conversion Capability. Second Round Review at MIS Quarterly.

[39] Sidiq, Ahmad danAstutik, ErniPuji, 2017, Analisis Kapabilitas TehnologiInformasiTerhadapKinerjaBisnis UKM dengan Orientasi PelangganSebagaiVariabel Intervening, Media EkonomiManajemen Vol 32 No 1, Januari 2017 pp 9 - 27

[40] Slamet, H. R. Margono, 2003, Membentuk Pola PerilakuManusia Pembangunan, IPB Press, Bogor

[41] Tavakoli, Arvin, 2013, Impact of Information Technology on Entrepreneurship Development, Advances in Environment Biology 7 (8) pp.1421 - 1426

[42] Uncles, M. (2000). Market Orientation. Australian Journal of Management. Vol.25, No.2.

[43] Wahyono, 2002. Orientasi Pasar dan Inovasi: PengaruhnyaTerhadapKinerjaPemasaran (Studikasus pada IndustriMeubel di KabupatenJepara). JurnalSainsPemasaran Indonesia, Vol I, No 1 Program Magister Manajemen. UniversitasDiponegoro.

[44] Weerawardena, J. .2003. Exploring The Role of Market Learning Capability in Competitive Strategy. European Journal of Marketing. Vol.37, pp.407 - 429.

[45] Wirawan, YahyaReka, 2017, PengaruhOrientasiPasar, OrientasiKewirausahaanTerhadapKinerjaPemasaran

UMKM Batik di KabupatenJombang, Jurnal Equilibrium Volume 5 Nomer 1 Januari 2017 pp.56 69

[46] Wurjaningrum, F., Hartami, B., 2018, The Intervening Effect of Market Orientation on Entrepreneurial Orientation, Operations Strategy, and Business Performance, Advances in Economics, Business and Management Research, volume 117, pp.170 - 173

[47] Zhao, Fang, 2008, Information Technology Entrepreneurship and Innovation, Information Science Reference, Hershey, New York

[48] Zhou, K. Z., Yim, C. K, Tse, D. K., 2005, The Effects of Strategic Orientations on Technology - and Market Based Breakthrough Innovations, Journal of Marketing Vol 69, Issue 2

[49] Zhang, M., Sarker, S., \&Sarker, S., 2008, Unpacking the effect of IT capability on the performance of exportfocused SMEs: a report from China. Information System Journal, 18 (4), pp.357 - 380.

\section{Author Profile}

AchmadZaini is a lecturer in the Department of Business Administration at the State Polytechnic of Malang, East Java, Indonesia with competence in marketing and entrepreneurship.

Diana Eka Poernamawati is a lecturer in the Department of Business Administration at the State Polytechnic of Malang, East Java, Indonesia with competence in marketing and business. 